\title{
A J Williams-a tropical veterinary pioneer
}

\author{
G R Durrant CBE L/RAVC
}

J R Soc Med 2003;96:465-466

Many of the early developments in human and veterinary medicine were brought about by members of the military medical and veterinary services. This is particularly true of tropical diseases. For example, the organism Trypanosoma evansi reminds us that, in 1880, Colonel Griffith Evans MD FRCVS, of the Army Veterinary Service, postulated the pathogenicity of the trypanosome and its spread by fly bites. Initially the idea was bluntly rejected by his military medical superiors. It was largely the study of his report by Koch and Pasteur that led to Evans' recognition as discoverer of the pathogenicity of the trypanosome ${ }^{1}$ - truly a landmark in tropical medicine. Recently, when visiting a veterinary colleague, I met a retired colonel of the Royal Marines whose grandfather had been Director of Veterinary Services in India 1928-1932. He too, I found, made striking contributions to tropical veterinary medicine.

Augustus John Williams was born at Usk, Monmouthshire, in 1876. He qualified as a veterinary surgeon at the Royal (Dick) Veterinary College at Edinburgh at the age of 21 and, having passed the Army Veterinary Department entrance examination, was gazetted Veterinary Lieutenant in July 1898. That year saw publication of a new War Office edition of War Establishments that omitted provision of any kind for the care of sick animals in the field. ${ }^{2}$ This omission was to have the most appalling consequences. In October 1899 the South African War broke out and four weeks later Williams set sail for his first overseas tour of duty, which was to last for 3 years. After service in South Africa he was awarded the Queen's South Africa Medal with four clasps and the King's Medal with two clasps. The brief entry on his record sheet cannot convey the scale of the clinical and regimental experience he would have gained during those years. Major General Sir Frederick Smith's Veterinary History of The War in South Africa describes a veterinary disaster of huge proportions. Two-thirds of the horses were lost, almost all through poor management or infectious disease. Veterinary officers struggled desperately to improvise an organization in the absence of any previous planning and preparation. When hostilities ceased, the disposal of surplus animals spread epidemics throughout South Africa, as did those returned to the $\mathrm{UK}$, and the outbreaks lasted for several

Yew Tree Cottage, Windmill Hill, North Curry, Taunton TA3 6NA, UK Correspondence to: Brigadier G R Durrant years. ${ }^{3}$ The bitter lessons learned in South Africa would have made a profound impression on Williams and his colleagues. One beneficial consequence of this debacle was the formation of the Army Veterinary Corps (AVC) in 1903 and the total reorganization of veterinary mobilization and deployment policy.

After his tour of duty in South Africa, Williams was posted to India for 3 years. This was to provide little respite because he was soon on active service again. The Younghusband expedition of 1903-1904 to Tibet was not one of the most glorious episodes in British military history, but for Acting-Captain Williams and his four veterinary comrades it must have been a great adventure. The infantry force consisted of two thousand Gurkhas and Sikhs, and in support were ten thousand porters, seven thousand mules, four thousand yaks and numerous riding animals. ${ }^{4}$ The endless straggling column travelled through almost unknown territory, often at more than 15000 feet $(4600 \mathrm{~m})$. By the end of this episode Williams would have been a very experienced veterinarian indeed. Awarded the Tibet Medal, he returned to India and in 1905 passed the promotion examination for substantive rank.

At last, in November 1905, Williams was back on home establishment. In the eighteen months of this posting he obtained his Fellowship of the RCVS by examination and attended a postgraduate course at Liverpool University. In May 1907 he was seconded to the Egyptian Army for service in the Sudan. The Sudan Veterinary Service was formed by British officers in 1898 and staffed by them until 1924. Here Williams wrote a paper on a virulent outbreak of foot and mouth disease. Returning home with the Khedive's Sudan Medal, he was promoted major. A single line on his record sheet states that he reported on an outbreak of equine contagious pleuropneumonia at Longmoor Garrison in 1910. This disease was prevalent in military stables housing large numbers of horses, and on transport ships, with high mortality. The use of serum was pioneered by the Corps and, after the first year of the 1914-1918 war, losses were greatly reduced.

In 1912 Williams was again posted to India, where he was to begin the most important work of his career. The tick-borne disease piroplasmosis or biliary fever, now known as babesiasis, had long been a scourge of military horses in India and the East. ${ }^{5}$ The wastage from sudden death or severe debility when on campaign was of grave 
importance. Williams was only one of the Army Veterinary Corps officers engaged in the research, but it was he who developed the 'biliary fever outfit'. This equipment was used to give intravenous injections of quinine acid hydrobromide, a specific for the condition which was most effective when used at an early stage. The disease was particularly troublesome in Mesopotamia (now Iraq) where, as the Official History of The War states, 'the treatment of this disease had proved of little avail . . . until the advice and help of Lt Col A J Williams was obtained, this produced excellent results' ${ }^{6}$ Williams was posted to Mesopotamia in 1917, and his Circular Memorandum of 31 October 1917 concerning biliary fever is a model of clarity. His dictum was 'if in doubt inject'. Thereafter, the disease was brought under control and the importance of this achievement for the supply and transport of the Army is apparent from the fact that in 1918 there were more than eighty thousand horses and mules on strength in Mesopotamia. Williams' report in the Tropical Veterinary Bulletin ${ }^{7}$ is still cited in scientific publications and Clabby's History of the RAVC 1919-19613 states that Williams' method 'was used successfully for more than fifty years'. Williams was twice mentioned in despatches and was awarded the DSO.

Those of us who served in Singapore and Malaya in the 1960s will remember the very heavy mortality rate among military dogs of the British Army and also those of the US Army in Vietnam. The cause was likewise a tick-borne disease, canine erlichiosis or tropical canine pancytopenia. Despite advanced research facilities and modern therapeutics, it was several years before we fully understood the disease and brought it under control, yet with empirical methods, primitive equipment and rudimentary medicaments Williams was able to bring babesiasis under control within just a few months, when it threatened the whole logistic system.

Now a substantive Lieutenant Colonel, Williams was appointed Commandant of the Royal Army Veterinary Corps School at Aldershot in 1923, but in 1924 he returned to India. As Director of Veterinary Services India from 1928 he strongly encouraged his officers to apply new ideas and methods. One of these, lately developed at the Mukteswar Research Station, was the treatment of surra (equine trypanosomiasis) with intravenous and intrathecal naganol ('Bayer 205'). As a result of its application in military operations in Burma in 1931, no horses or mules were lost, whereas in former times mortality there had been very high. ${ }^{3}$ This innovation must have been of great benefit in Burma in the Second World War when large numbers of horses and mules were used by the 14th Army.

Retiring in 1932 Brigadier Williams could look back on many notable achievements, but none greater than his work on babesiasis.

\section{REFERENCES}

1 Ware J, Hunt H. The Several Lives of a Victorian Vet. London: Bachman \& Turner, 1979

2 Smith F. A History of The Royal Army Veterinary Corps 1796-1919. London: Baillière Tindall \& Cox, 1927

3 Clabby J. The History of The Royal Army Veterinary Corps 1919-1961. London: Allen, 1963

4 Hopkirk P. The Great Game. Oxford: Oxford University Press, 1991

5 Bone JF, Catcott EJ, eds. Equine Medicine and Surgery. Santa Barbara: American Veterinary Publications, 1963

6 History of The Great War Based on Official Documents-Veterinary Services. London: HMSO, 1925

7 Williams AJ. Report of the treatment of Nuttaliosis in army horses. Trop Vet Bull 1916;4:3 